\title{
WHERE HAS THE OLD \\ DEBATE GONE? REALISM, INSTITUTIONALISM AND IR THEORY
}

\author{
Rafael Grasa and Oriol Costa
}

$2007 / 5$

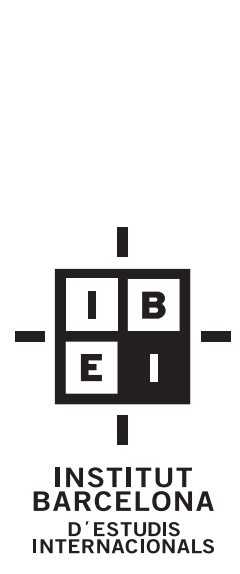

Rafael Grasa (1st co-author)

$\mathrm{PhD}$ in Philosophy. Lecturer of IR at the Autonomous University of Barcelona and Secretary-General of the UAB. Formerly dedicated to epistemology, science theory and mathematical logics, he later shifted to political science and International relations. Lecturer at the IBEI. Advisor

Rafael.Grasa@uab.es

\section{Oriol Costa (2nd co-author)}

$\mathrm{PhD}$ in International Relations. Junior lecturer of IR at the Autonomous University of Barcelona (UAB) and member of the Observatory of European Foreign Policy at the University Institute of European Studies (UAB). Main areas of interest are international environmental politics and IR theory.

Oriol.Costa@uab.es 


\section{IBEI WORKING PAPERS}

$2007 / 5$

Where Has the Old Debate Gone? Realism, Institutionalism and IR Theory

(C) Rafael Grasa and Oriol Costa

(c) IBEI, de esta edición

$\begin{array}{ll}\text { Edita: } & \text { CIDOB edicions } \\ & \text { Elisabets, } 12 \\ & \text { 08001 Barcelona } \\ & \text { Tel. } 933026495 \\ & \text { Fax. } 933022118 \\ & \text { E-mail: publicaciones@cidob.org } \\ & \text { URL: www.cidob.org }\end{array}$

Depósito legal: B-21.147-2006

ISSN:1886-2802

Imprime: Cargraphics S.A.

Barcelona, February 2007 


\title{
WHERE HAS THE OLD DEBATE GONE? REALISM, INSTITUTIONALISM AND IR THEORY
}

\author{
Rafael Grasa and Oriol Costa
}

\begin{abstract}
This paper resorts to the contribution of the science philosopher Gerald Holton to map some of the IR arguments and debates in an unconventional and more insightful way. From this starting point, it is sustained that the formerly all-pervading neorealism-neoinstitutionalism debate has lost its appeal and is attracting less and less interest among scholars. It does not structure the approach of the theoretically-oriented authors any more; at least, not with the habitual intensity. More specifically, we defend that the neo-neo rapprochement, even if it could have demonstrated that international cooperation is possible and relevant in a Realist world, it has also impoverished theoretical debate by hiding some of the most significant issues that preoccupied classical transnationalists. Hence, some authors appear to be trying to rescue some of these arguments in an analytical and systematic fashion, opening up a theoretical querelle that may be the next one to pay attention to.
\end{abstract}

Key words: Realism, Liberalism, Institutionalism, IR Theory, IR Debates, Gerald Holton, Epistemology and International Relations, Paradigmatism.

This paper was presented at the at the section on International Relations of the 2006 National Conference organized by the Midwest Political Science Association (panel: Realism's Ancient Roots and Modern Relevance), 20-23 April 2006, Chicago (USA). 


\section{Introduction}

The opposition between realists and institutionalists, in whichever of their guises, has had a major influence for many years over theoretical work in International Relations (IR). However, this dispute seems to have lost the centrality that it enjoyed until recently. The current paper seeks to explain why the debate between neorealists and neoinstitutionalists (or neo-neo) is no longer the main reference point for theoretical debates in IR; to suggest which debate now relates to the same classic questions; and, in particular, to show how this disappearance highlights the limits of the way in which the discipline has mapped itself and its theoretical debates with a certain degree of theoretical bias. On this final question, our starting point is the contribution of Gerald Holton (1973), an author whose work has already been used in International Relations ${ }^{1}$, and the introduction of the 'thematic component' in the history of science and of thought.

The text is divided into five sections, apart from this introductory one. The next one justifies the relevance of the subject under discussion. The third presents the contributions of Gerald Holton and discusses how they will be used in the rest of the paper. The forth section seeks to review the transition between the so-called interparadigmatic and the neo-neo debate, and to explain its main consequence in terms of the relations between neorealism and neoinstitutionalism, namely the analytical convergence between the two schools of thought. The following section examines recent attempts to separate them (in order to identify them), and maintains that such attempts have failed. It is precisely this marked coming together of the analytical frameworks used by both schools that, from our point of view, explains the loss of interest in the neo-neo debate. Finally, the sixth section suggests which theoretical debate might now come to the fore, and shows how basic issues of classical IR debates seem to be emerging in new forms.

\section{The Incredible Shrinking Debate}

The debate between realists and institutionalists has constituted the mainstream of IR since its inception as a consolidated academic discipline. Its issues and arguments have focussed the attention of authors and have informed the questions, research programmes and conjectures and hypothesis: the possibility and relevance of co-operation; the explanatory value of anarchy, state-centeredness and the role of new actors; and, finally, the problems associated with change and continuity in international society. In addition, during the 1980s and 1990s, the challenge of constructivism led to the opening of new lines of battle in the debate, uniting (neo)realists and (neo)institutionalists under the banner of rationalist epistemology, against the so-called reflectivist school, closer to relativist postulates.

Hence, the traditional form of mapping IR has presented the discipline as a field of thought crossed by two, distinct debates. On the one hand, the long-standing neo-neo debate, which is partly a re-edition of the quasi-mythological debate between realists and idealists, and of the so-called 'third' or

1 The work of Gerard Holton was first introduced into IR by Yosef Lapid, with the objective of shedding light on the opportunities and risks of the arrival of post-positivism for IR, which, he argued, was embodied in the third debate of the discipline (Lapid, 1989: 239). See also Rafael Grasa (1997). Already in the 1970s Holton's work had stimulated important reflections: see Merton (1975) and Holton (1975). 
'interparadigmatic' debate. On the other, we find the opposition between reflectivists and rationalists, a much more meta-theoretical debate which is undoubtedly linked to theoretical disputes affecting social sciences as a whole in the period after the hegemony of positivism.

However, perhaps paradoxically, the debate between neorealists and neoinstitutionalists seems to have attracted less academic interest, and has waned to such an extent that it no longer shapes the work of theoretically-oriented authors. Thus, for example, since the year 2001 (and as of February 2006) in the European Journal of International Relations ${ }^{2}$ only two articles have centred on the longest-running dispute within IR, and one of those was written from a retrospective point of view ${ }^{3}$. We might also wish to repeat the exercise for other journals, such as International Security and International Organization, given their undoubted importance, their origins and the diversity of their respective approaches. A similar situation emerges, whereby the former has published four articles ${ }^{4}$ of this kind since 2001, while none can be found in the latter. Put another way, what was once the all-pervading debate of the discipline no longer seems to be at the centre of analytical and theoretical attention in IR. As such, the discipline now seems to be dominated by the division between rationalists and reflectivists. This is reflected in the terms introduced by eight out of the ten most-cited articles of the European Journal of International Relations: 'norms', 'constructing', 'constructivism', 'identity', 'socialization', 'culture', 'discourse', 'rationalist-constructivist divide', 'persuasion', 'norm construction'5.

This is, without doubt, a significant shift in the reference points that have shaped the discipline up until now. Hence the questions that inform our reflection: What are the factors behind the decline of the debate between realists and institutionalists?; Have the questions and issues surrounding such a debate disappeared altogether, or must we search them out elsewhere? In other words, are there other emerging debates, still difficult to identify, that are taking over from or subsuming the former debate? And, finally, if the majority of the traditional themes are now approached in a different way, in other places, or using different analytical frames, shouldn't we ask whether part of the problem lies in the lack of suitability of the analytical tools and the mapping of theoretical reflection in IR? Should we, thus, continue to use the same instruments to identify the lines of division and the recurrent themata?

We propose a different approach to the theoretical debates in the discipline, that in our opinion is more useful, and we shall do using the thesis of Gerald Holton on the structure of scientific discourse and, in particular, the thematic component and the role of themata in scientific thought.

\footnotetext{
2 This is an approximate exercise, given the difficulty involved in examining both the limits of the debate and, on occasions, the degree of priority ascribed to it in certain articles. However, the overwhelming results of the exercise seem to lend weight to our claim.

3 We refer to Thies, Cameron G. (2002), 'Progress, History and Identity in International Relations Theory. The Case of the Idealist-Realist Debate', European Journal of International Relations, Vol. 8, No. 2, 147-186; and Guzzini, Stefano (2004), 'The Enduring Dilemmas of Realism in International Relations', European Journal of International Relations, Vol. 10, No. 4, 533-568.

4 We refer to Rosencrance, Richard (2001), 'Has Realism Become Cost-Benefit Analysis? A Review Essay', International Security, Vol. 26, No.

2, 132-154, that in fact reflects perplexity in the face of the difficulties experienced by the old categories to explain most-recent theorization, to which we will refer to in the forth section; Owen, John M. (2001/02), 'Transnational Liberalism and U.S. Primacy', International Security, Vol. 26, No. 3, 117-152; Zinder, Glenn H. (2002), 'Mearsheimer's World -Offensive Realism and the Struggle for Security: A Review Essay', International Security, Vol. 27, No. 1, 149-173, which is, in fact, an article concerning the most recent debates within realism; and Schweller, Randall L. (2004), 'Unanswered Threats: A Neoclassical Realist Theory of Underbalancing', International Security, Vol. 29, No. 2, 159-201.

5 The list of the 50 most cited articles of the EJIR can be found at the web site of SAGE Publications, http:/ / ejt.sagepub.com. Here we cite the list as of $02 / 02 / 2006$.
} 


\section{The Axes of Gerald Holton and the Thematic Component in International Relations}

At the end of the 1960s and beginning of the 1970s, the generation at work in philosophy, history and sociology of science showed a great interest, not devoid of collisions and controversy, in the cognitive and social structure of the scientific enterprise. From these years we have inherited, in a context of increasing paradigmatism, 'scientific community' and 'tacit knowledge' from Polanyi, 'falsicationism' and 'third world' from Popper, 'paradigms, disciplinary matrices and normal science' from Kuhn, the 'research programmes' from Lakatos, 'evolutionary epistemology' from Campbell, 'images of science' from Elkana and 'normative structure of science' from Merton. Of all those mentioned, the discipline of International Relations has habitually turned to Kuhn.

Meanwhile, silently, as Robert K. Merton recalled, Holton ${ }^{6}$ had been sketching out his concept of 'thematic analysis', a way of interpreting that 'assumes underlying elements in the concepts, methods, propositions, and hypotheses advanced in scientific work' (Merton 1975: 335). The use of a term with a long tradition (anthropology, art criticism) pointed to the idea that the themata, that are normally absent from explicit and public presentations of scientific results (context of justification, in epistemological language) usually play a key role in 'constraining or motivating the individual and sometimes guiding (normalizing) or polarizing the scientific community' (Holton 1975: 330)

From this, in addition to the two most usual kinds of meaningful propositions in science (phenomenic and analytical) that make up the so-called contingent plane (the plane of the 'study of relevance of concepts and propositions, the operational analysis in its widest sense', Merton 1973: 12), a third kind arose, the themata, that are understood as fundamental preconceptions of a stable and widely diffused kind that are not derivable from observation and analytic ratiocination. In sum, as Holton said many years later, 'a scientific statement is no longer an element of area in two-dimensional plane, but a volume-element, an entity in three-dimensional spaces, with components along each of the three orthogonal (phenomenic, analytic and thematic) axes' (Holton 2003: 10)

Thus, according to Gerald Holton, scientific discourses are made up of three kinds of arguments, or axes, each distinct. In the words of Yosef Lapid, the three are: (1) phenomenic, that is 'the empirical content of scientific theories'; (2) analytical, that is 'hypotheses, explanations, and theoretical models'; and, finally, (3) thematic, that include 'reality-defining assumptions, epistemological premises, and other types of distinctly 'ideological' or 'metaphysical' ingredients', in addition to ontological ones (Lapid, 1989: 239). Let us look at each one in turn.

The usefulness of the distinction, while mentioned by Lapid, was not fully exploited. As is known, we choose analytical propositions in function of their suitability regarding our aims, given that 'there exist in principle infinitely many possible logical and mathematical systems', and thus they may even be mutually incompatible. As such, on the analytical axis, propositions are measured according to

${ }^{6}$ The basic bibliography referred to in this section is: a) Holton 1973, pp. 11-44 (Introduction) and 21-29; b) Holton 1975; c) Holton 1998; d) Robert K. Merton (1975); and e) Markova 2004. 
their analytical utility, which varies according to the issue to be analysed. (Holton, 1973: 54). The propositions of the second axis, the phenomenic ones, do not enjoy the same 'degree of freedom', given that 'we seem constrained to deal with the phenomena [...] as they present themselves' (Holton, 1973: 54-5). However, as argued, not all scientific activity fits on the contingent plane. Specifically, 'preconceptions that appear to be unavoidable for scientific thought, but are themselves not verifiable or falsifiable' (Holton, 1973: 23), the themata, are absent. Of course, the arguments and statements of the thematic axis 'are not proved or disproved', are not 'resolvable into or derivable from observation and analytical ratiocination', and as such 'they rise and fall and rise again with the tides of contemporaneous usefulness or intellectual fashion' (Holton, 1973: 62 and 24).

By way of conclusion, the analytical and the phenomenic axes are those that form part of public, institutionalised, regulated science that is subjected to the parameters of scientific evaluation. On the other hand, in order to understand the part of scientific activity that is linked to 'personal struggle', that is often 'illogical', 'irrational', driven by 'unscientific motivations' and by 'passionate motivations', and comes prior to the other form of science, one must turn to the thematic (Holton, 1973: 18).

From our point of view, Gerald Holton's formulations are interesting for a number of reasons. Firstly, they point to the fact that arguments can be of distinct natures (in fact, what happens is that each argument is projected differently in each of the axes) and that, consequently, they must be evaluated using distinct criteria. In effect, once the differentiation between the two parts of scientific activity, the thematic and the contingent, has been established 'one is ready to work in the world [of themas] without offending judgments [based on scientific rigor] that more properly belong to the [contingent] region'. And in the same way that one should be capable of separating the logics of the context of discovery from those of the context of justification, it would be naive to deny that often the impulse behind scientific activity stems from the unscientific, that on occasions is projected onto results (even if the latter are never justified by the former) (Holton, 1973: 20). Similarly, it must also be recalled that the evaluations of the analytic and the phenomenic should also be differentiated, given that in the case of the former what is evaluated is the utility of a given conceptual construction for analysing reality, while in the case of the latter the emphasis is on the capacity to capture reality ${ }^{7}$. Using a geometric metaphor, as occurs with two three-dimensional objects, two scientific statements may not coincide even though they may be similar in one or two of its dimensions.

The second reason for using Holton's three axes is that they prove to be most useful when ordering (and differentiating) the arguments present in complex debates such as the realistsneoinstitutionalists one. Indeed, as Stanley Hoffmann (1963: 26) points out, the theoretical arguments in IR debates are like airplanes that fly at different altitudes and in different directions. As we hope to

\footnotetext{
${ }^{7}$ Let us turn to perhaps the most classic example. The statement 'the mass of body is concentrated in one point' is unsatisfactory from a phenomenic point of view (it is a bad description of reality), but, on the other hand, as Newtonian physics testify, it has become a useful theoretical assumption (it is a good concept to proceed with the analysis). Certain statements concerning international reality also deserve different evaluations according to the axis on which the person making them wishes to place them. As such, to cite another well-known example, the rationality and unity of international actors might seek to be either a description of reality (phenomenic axis) or a starting hypothesis to explain other aspects of international reality (analytical axis). In the latter case, validity will be judged on the basis, not of its veracity (its descriptive precision) but rather on its analytical utility, which will depend on the research questions which are to be answered.
} 
demonstrate, the tripartite distinction between the thematic, the analytic and the phenomenic has the advantage of organising this complex air traffic in an insightful manner. More specifically, it allows us to capture the multidimensionality of the relations between the major theoretical approaches, which becomes even more important when such approaches, as well as their debates, evolve and are reformulated. Holton himself said that 'thematic analysis can serve to identify the particular map of the various themata which, like fingerprints, can characterize an individual scientist or a part of the scientific community at a given time' (Holton 2003: 10). The oft-debated issue of the commensurability or incommensurability of paradigms thus takes on new meaning: there may be incommensurability on the thematic axis, but this is impossible on the phenomenic axis, while on the analytic axis there may exist discrepancies that allow us to contrast and compare. Or, in other words, on the thematic axis, the meta-theoretical debate (and hence not theoretical in the strong sense of this word) takes precedence.

The next section seeks to observe this kind of developments.

\section{The Realist-Institutionalist Debate From Holton's Approach}

The approach presented in the above section allows us to re-examine in a more systematic way the debate between neorealists and neoinstitutionalists and also to evaluate the transformation of the debate in a more qualified and complex way. The theoretical dispute between the two schools of thought has the third debate in International Relations as its most immediate precedent; thus, we shall present the main features of this debate using Holton's terms, in order to observe how it later evolved into its most recent version (neo-neo).

As Michael Banks has suggested, the term 'inter-paradigm debate' (Banks, 1985) is much more enlightening, given that, as we shall argue, the third debate had two features: (1) there was no significant agreement between realists and institutionalists across any of the three axes (thematic, analytic or phenomenic); and (2) a significant number of authors highlighted controversies with a high thematic content, in Holton's sense. Let us now turn to these two parts.

1. There was practically no shared ground between authors from different schools. In each one of the axes, and in particular on the thematic one, it was more a question of what separated the two 'paradigms' than what they had in common. Firstly, concerning the thematic axis, it would not be going too far to argue that the most important legacy that the third debate inherited from the first was precisely the opposition between distinct cosmovisions (Morgenthau, 1948: 3). Thus, the work of realists was heavily shaped by the scepticism developed in the inter-war period and the anthropological pessimism inherited from what Martin Wight called the Maquiavellian tradition (Wigth, 1991; Morgenthau, 1948: 4). As Robert Gilpin noted, political realism 'is best viewed as an attitude regarding the human condition', and as such 'moral scepticism [...] constitutes the essence of realism' (Gilpin, 1986: 306-21). On the other hand, normative force was the strongest link between the transnationalists of the 1970s and the idealists of the inter-war period. Thus the former, in addition to highlighting and being critical of the anthropological pessimism of realism (Keohane, 
1986: 10-11), sketched out, defended and promoted 'an international framework of co-operation and order', in which 'economic (commercial, financial) and technological (communications)' were said to be 'the instruments for the construction of a global society' (Barbé, 1987: 165).

Also the analytical instruments used by both schools were different. In fact, transnationalism came into being in order to argue that 'states are by no means the only actors in world politics'; that the separation, at the heart of realism, between the domestic and international spheres should be rejected; that, consequently, states should no longer be considered as unitary and rational; and that the degree of conflict between states' interests, as well as their power, were not homogeneous throughout international relations as a whole and depended on the issue area in question (Keohane and Nye, 1971: x, 379-83). Overall, in its first guise, transnationalism maintained that none of the realist assumptions was useful (or relevant) for the study of international society in the last third of the twentieth century. Finally and with regards to the phenomenic axis, the schools participating in the debate portrayed reality differently and even failed to agree on which part of reality should be the object of study in IR.

2. Either way, it was the thematic axis that was the centre of controversy. It is on such an axis that we find incommensurability, since debate is more concerned with a priori positions than statements capable of being analized. The relevance granted to the meta-theoretical meant that the remaining aspects of the discussion were also characterised by incommensurability. This is what Guzzini was referring to when he complained of the lack of arguments that justified 'why value-incompatibility should exclude a rational debate, or the rapprochement of writers of different ideology'. In any case, the truth is that 'the inter-paradigm debate in fact [sought], and [did], mobilize a strong meaning of incommensurability which suggests that [...] debates across schools of thought are inconclusive' (Guzzini, 1998: 118).

To sum up, the emphasis on the thematic, together with the absence of common ground between diverse approaches, explains why the third debate was characterised more by confrontation than by debate in the strict sense of the word. Such a situation would not be resolved until the 1980s, when distinct lines of debate were defined, thus breaking the vicious circle associated with the unyielding nature of the schools of thought. In effect, the reformulation of realism into neorealism and of institutionalism into neoinstitutionalism modified the structure of the debate between the main theoretical approaches to International Relations. The spaces of agreement and disagreement between schools changed.

Certainly, as Kenneth Waltz himself pointed out, his Theory of International Politics (Waltz, 1979) had among its objectives the following: 'develop a more rigorous theory of international politics than earlier realists had done', and 'suggest some ways in which the theory can be tested and provide some examples of its practical application' (Waltz, 1986: 322). That is, (neo)realism opted to abandon 'general speculation and reflection' in favour of 'express[ing] itself in the form of theory, of a system of clearly specified sentences'. Realism '[was] no longer an ethico-philosophical position', and the 'sweeping statements on the nature of life and politics' had been substituted for 'precise statements' (Waever, 1996: 162). Expressed in the terms of the present paper, realism shifted its emphasis from the thematic to the analytic and the phenomenic: from incommensurability to verification and refutation. The evolution of institutionalism towards neoinstitutionalism (Keohane and Nye, 1977) took place in a parallel fashion: from being 'a general interpretation of the nature of international relations' to be 'concentrated instead on asking a few precise questions' (Weaver, 1996: 162; Keohane, 1989: 2). 
Together with this loss of importance of the thematic, the debate between realists and institutionalists underwent a further transformation that was just as important or more so, namely a marked convergence of the two disciplines on the analytical axis. As such, since that time neorealism and neoinstitutionalism coincide (1) in their rationalism; (2) in their state-centredness; (3) in assuming stable preferences over time among actors, which is related to the systemic roots of both schools; and (4) in highlighting anarchy as the structuring element of the international system (Hasenclever et al., 1997: 23 and following). In this sense, the proposition formulated by Keohane in 1986 is revealing in that it called for a 'modified structural research program', inspired in microeconomic theory, and that fulfilled the criteria of being systemic, state-centric and based on the assumption of rationality (Keohane, 1986: 192-94).

Thus, neoinstitutionalism developed by adopting the analytical tools of collective action, with the objective of demonstrating that self-interested actors in a context of anarchy are capable of cooperating. ${ }^{8}$. And that has two interesting readings. Firstly, such scholars showed that accepting the central assumptions of realism does not necessarily mean that the conclusions of realists concerning $\mathrm{co}^{-}$ operation in international society should likewise be accepted'. Secondly, although differences continue to exist in the thematic, neorealists and neoinstitutionalists now share many of their frameworks of analysis. This scenario has provoked reactions that appear to reveal a certain degree of dissatisfaction regarding the capacity of the old labels to now define the limits between the two theoretical approaches ${ }^{10}$.

Thus, some authors seek formulae to differentiate more clearly between the analytical tools of neorealists and neoinstitutionalists, which was often related to the desire of the former to respond to the 'challenge' presented by the latter (Kegley 1995), who had sought to demonstrate that 'they can undercut realism even while using the latter's own basic premises and propositions' (Grieco, 1990: 9). The next section examines the main attempt to distinguish between the analytical arguments of the two schools of thought; that is, the argument of relative gains.

\footnotetext{
${ }^{8}$ The literature on international regimes, so prolific during the 1980s and 1990s, can be understood precisely within this logic of the neo-neo approach, that brought the analytical tools used by realists and institutionalists closer. As Andrew Hurrell wrote, 'on the one hand, there was the need to achieve maximum distance from such perceived formalism [in international law] and from anything tainted by the sins of idealism', and, on the other, 'to be academically credible, ideas of co-operation had to take into account the harder world of early 1980s, the structuralist turn in the overall direction of international relations theory, and the need to achieve as much theoretical rigour as the other social sciences [and specially microeconomics] had purportedly been able to do' (Hurrell, 1993: 53). This is probably why, in the words of Stephen Krasner, 'what distinguishes the regime concept [...] from its most obvious lineage [functionalism, neofunctionalism, linkage politics, and transnationalism, as well as the idealism of the interwar period] is that it has attracted a number of scholars who have been primarily identified with the realist tradition' (Krasner, 1983: 355).

${ }^{9}$ Otto Keck maintains that what he calls rational institutionalism 'has demonstrated that cooperation is possible even on realist premise', and that as such it has demonstrated the absence of a logical link between such premises and 'the scepticism by realists against international institutions' (Keck, 1993: 36). From not too-distant positions, although on this occasion claiming to belong to the school of 'contingent realism', Charles L. Glaser also argues that realist premises do not necessarily lead to the conclusions maintained by realists. 'I argue that this pessimism is unwarranted. Contrary to the conventional wisdom, the strong general propensity for adversaries to compete is not an inevitable logical consequence of structural realism's basic assumptions' (Glaser, 1994/95: 51).

10 Reference is made to, for example, the article by Legro and Moravcsik (1999), entitled, precisely, 'Is Still Anybody a Realist?', and the replies and counter replies that it provoked (Feaver et al., 2000). The article by Rosecrance, published in 2001 with the significant title of 'Has Realism Become Cost-Benefit Analysis?' regarding the book by Gruber (2000), can also be interpreted in this light
} 


\section{Relative Gains}

Indeed, neorealists were forced to mention relative gains in their list of basic assumptions, on both the thematic axis and the analytical axis. In the words of John J. Mearsheimer, 'a theory that explicitly accepts realism's core assumptions [...] must confront the issue of relative gains if it hopes to develop a sound explanation for why states co-operate' (Mearsheimer, 1994/95: 20). It was a question of separating both schools of thought on what, to judge from the arguments made, seemed to be the very epicentre of their differences.

According to neorealists, the problem laid in the limited comprehension of anarchy on the part of neoinstitutionalists, who restricted themselves to the problem of fraud and deception and failed to understand the issue of violence and survival (Grieco, 1995: 154; Powell, 1994: 330-1). For neorealists, anarchy is significant because it raises issues of survival, that in a context of anarchy is assured through power: 'the fundamental goal of states in any relationship is to prevent others from achieving advances in their relative capabilities' (Grieco, 1995: 161, see also Grieco, 1993: 729, and Grieco, 1990: 10). In short, neorealism maintains that states are not atomistic and selfish, but rather 'negative altruists' (Taylor, 1987: 111) and positional.

Throughout the lengthy and bitter debate over relative gains, neoinstitutionalist authors put forward three areas of critique. Firstly, it was maintained that the above-mentioned argument confuses cause and effect, in that it suffers from indeterminacy that seems to indicate that the importance of relative gains depends on other factors in international life that could be captured directly. Secondly, it was considered that the concept of relative gains was not sufficiently clear, and as such they came to be articulated around other concepts that border on the concept of relative gains, but that are neither identical nor far from what institutionalists had developed. Finally here, some academics used the language of game theory to show how relative gains have little or no impact on the possibilities of cooperation. Such arguments, as we shall see in more detail, are meta-theoretical, thematic and analytical, but not phenomenic.

As Robert Powell pointed out, if one accepts the preoccupation over relative benefits, two possibilities exist. The first is that this preoccupation (referred to as $k$ henceforth) varies, and it 'is the product of the strategic environment in which the state finds itself' (Powell, 1994: 335). Thus, for example, Joseph Grieco highlights that $k$ increases if states go from a relation in keeping with a security community to one closer to a state of war (Grieco, 1995: 163). The second possibility is that, unlike the first, we assume that $k$ 'do[es] not vary and is the same regardless of its environment' (Powell, 1994: 335). A review of the literature quickly shows that neither neorealists nor neoinstitutionalists argue in favour of the second option.

Indeed, the problem with focusing on relative gains is that if we accept that the degree of concern over them varies, then it must be accepted that such variations deserve explanation (Legro and Moravcsik, 1999: 25). Relative gains are no longer useful to explain the presence or absence of cooperation between states, but rather need to be explained. In order to do so, a clearly liberal discourse has been used on several occasions. Thus relative benefits have abandoned the analytical axis and have entered the phenomenic one. As Keohane and Martin wrote, 'the major lesson of the debate on relative 
gains is that their importance is conditional'. The debate on relative gains should not be over whether relative gains are important, but rather 'we need instead to ask under what conditions such distributional conflicts are severe' (Keohane and Martin, 1995: 44-45; Powell, 1994: 336).

Some authors developed a second area of critique, maintaining that arguments supporting relative gains lack sufficient conceptual clarity, and that, deep down, they offer nothing that can not already be found in neoinstitutionalist discourse. Thus, some neoinstitutionalist have insisted on the need to make a clear distinction between problems of a distributional nature and those concerning relative gains (Keck, 1993: 56). Similarly, Duncan Snidal argued that concern for relative gains 'can be criticized as a misspecification of an argument that could be better expressed in absolute gains terms', that is, in terms of a 'trade-off between short-term absolute gains (i.e., immediate payoffs from cooperation) and long-term absolute gains (i.e., security over the long haul)' (Snidal, 1991: 704). Finally, in a similar vein Helen Milner compared the concept of relative benefits with the combination of two terms that are strongly associated with neoinstitutionalism, when she maintained that the pursuit of absolute gains combined with reciprocity may be equivalent to the assumption that states focus on relative gains' (Milner, 1992: 471-2).

The third critique was based on game theory arguments, and sought to show that if relative gains can be operationalized in a relevant way (which contradicted the arguments already mentioned), then cooperation between states would not be affected. In this respect, it must be recalled Duncan Snidal's argument concerning 'competitive transformations', that examines the effects of an increase in the awareness of relative gains on the possibilities of co-operation for the main strategic situations studied by game theory ${ }^{11}$. According to Snidal, the main conclusion reached in the exercise is that relative gains concerns turn all games, sooner or later, into the prisoners' dilemma (PD); in other words the leastfavourable situation for co-operation. However, only the highest levels of $k$ produce intense DP (Snidal, 1991: 710). As such, except in the most extreme cases, 'the institutionalist case for the possibility of decentralized cooperation remains strong'12 (Snidal, 1991: 701). A similar conclusion was reached by Otto Keck (1993), who approached the subject through the use of indifference curves and studied the case of interactions with more than two actors.

Overall, it follows that the arguments in favour of relative gains do not appear to have been able to clearly distinguish the analytical tools of the two principal schools of International Relations, since they fail to engage with the real theoretical debate, that is linked to the explanation of particular phenomena. While at the beginning of this debate, the issue became the litmus test to distinguish between neoliberal and realist analyses, in the end it is highly likely that the choice between relative or absolute gains should not be made a priori, nor should we expect it to enable us to separate one from the other. (Powell, 1993: 735; Jervis, 1999: 46).

By way of summary of the last two sections, since the 1980s neorealism and neoinstitutionalism have undergone a notable degree of convergence with regards to their analytical tools, which have

11 For Grieco's reply, based on a critique of Snidal's assumptions, see Grieco (1993). For Sindal's counter, centred on the differentiation between problems generated by relative gains and those of a distributional nature, see Sindal (1993).

12 Michael Taylor has arrived, via a different path, to very similar conclusions. See Taylor (1987: 115). 
become virtually interchangeable. In fact, the convergence has been such that they have been able to overcome such tests as the debate on relative gains. Thus, despite the fact that the thematic differences between realists and institutionalists have remained, the analytical dimension of the debate has almost disappeared. In other words, the clash between both schools of thought continues to resonate in their respective works, but such conflict is no longer capable of articulating theoretical (or meta-theoretical) discussion. In effect, the latter is now dominated by the debate that exists between the reflectivist and the rationalist approaches, that are much more ontological by nature (and consequently more thematic).

Thus, there can be comparison and even collaboration along the phenomenic axis, thanks to the conmensurability and the ability to contrast empirically-based statements, and there can also be irreducible a prioris on the thematic axis. Without real debate on the analytical axis, theory in a strong sense is very mush diminished.

The following section suggests that, despite the fact that the instruments normally used to map the discipline have proved to be incapable of capturing it, it may be the case that a strictly analytical debate (in Holton's sense) may be re-emerging that takes up the issues forgotten during the period of the convergence of neorealists and neoinstitutionalists.

\section{The Re-Openning of the Analytical Debate?}

In this section, we argue that there exists a latent debate, still not sufficiently explicit, that is off the radar of the usual ways of describing the discipline, and that has the potential necessary to reopen the analytical axis to discussion. We shall identify some of its principal features and endorse the case for it to be taken fully into consideration.

We have argued that the neo-neo convergence allowed neoinstitutionalists to defend the possibility of co-operation, and that such co-operation is relevant even in a world based on realist assumptions. At the same time, it played down certain other dynamics of international society, that were removed from the most salient analytical debate of International Relations. We should, however, point out that such dynamics continued to be present in the work of several authors, especially in more phenomenic studies.

Thus, for example, the importance of domestic politics is frequently highlighted in the most phenomenic works of a wide range of authors, regardless of their analytical and thematic positions ${ }^{13}$. In effect, references to pressure groups, to public opinion, to the evolution of the structure of national economies, to relations between different levels of administrations, to the cosmovisions of those in government and to the personality of leaders abound in the literature.

${ }^{13}$ Keohane himself wrote that 'systemic analysis will not yield determinate predictions about states' pursuit of wealth and power';
and even if it did, 'these predictions would be subject to inaccuracy insofar as great variations in state behavior resulted from variations in their internal characteristics' (Keohane, 1984: 29). 
However, as Robert Putnam argued, references to domestic politics could be treated in a more systematic way (moved to the analytical axis), rather than being merely casuistic (simply phenomenic), as they have been up until now. In his own words, 'much of the existing literature on relations between domestic and international affairs consists either of ad hoc lists of countless 'domestic influences' on foreign policy or of generic observations that national and international affairs are somehow 'linked" (Putnam, 1988: 430). Helen Milner has also written along similar lines in that 'to understand the major issues in international politics', IR theorists 'must bring a systemic analysis of domestic politics into the field', avoiding the 'tendency to produce lists of variables more than theories' (Milner, 1998: 759, 773).

Part of the literature has emphasised that the projection of internal politics onto international politics is accompanied by the reverse: among the most relevant consequences of intergovernmental organizations (IGOs), regimes and other international institutions is the modification of domestic policies. Thus, for example, Rittberger and Zürn contemplate the hypothesis that international regimes might cause 'a reshaping of interests among the participating actors' (Rittberger and Zürn, 1990: 52). In fact, some have argued that 'perhaps the most important path which institutions can change preferences is through domestic politics' (Jervis, 1999: 61). It is interesting to note that the paths along which such interference by international institutions in domestic politics takes place coincide with the processes identified at the time by the first transnationalist authors ${ }^{14}$.

In those works with a phenomenic vocation, it is also common to find the argument that perceptions, knowledge and other cognitive factors condition the behaviour of states. In fact, even rationalist authors share this idea in their reflections on reality rather than in their attempts to explain it ${ }^{15}$. As Axelrod and Keohane pointed out, the existence of co-operation in a context of anarchy 'depends not merely on the three game-theoretic dimensions', that is, payoff structures, iteration and the number of players, but rather also 'on the context within which interaction takes place', that is, 'norms that are shared, often implicitly, by the participants', of the 'deep structure'16 (Axelrod and Keohane, 1986: 238). Other scholars have directed their efforts towards analysing 'the conditions under which behavior may change based upon a new understanding of the casual relationships in the world', underlining the role of the socalled ‘epistemic communities' (Haas, 1990: 52; Haas, 1993: 179).

However, in this case, too, it is difficult to find work that goes beyond recognising the importance of the ideational, or the mere phenomenic noting of its impact, and that proposes ways of incorporating them into the analysis ${ }^{17}$. The cognitive, then, either forms part of the ontological and

14 See Levy, Young and Zürn (1995: 211); Kahler (2000: 699); Mayer (1992: 793); Abbott and Snidal, (2000: 428); Young (1989: 79).

15 It must be recalled that in his The Evolution of Cooperation, no less, Axelrod recommended 'teach[ing] reciprocity' as one of the means of favouring co-operation (Axelrod, 1984: 136 and following). See also his reworking of the issue in The Complextyi of Cooperation. Agents-Based Models of Competition and Collaboration, Princeton, Princeton UP 1997.

16 See also Hurrell (1993: 79), and Corrales and Feinberg (1999: 17).

17 The theory of epistemic communities has been criticised precisely for its supposed lack of analytical content and for being toophenomenic a statement. As Levy, Young and Zürn wrote, 'studies of actual cases have made it clear that these arguments will require considerably more development in analytic terms before they can be properly tested as contributions to our understanding of regime formation' (Levy et al., 1995: 284). See Hurrell and Kingsbury (1992: 19); Berstein (2000); List and Rittberger (1992: 104) and Liftin (1995: 252). 
thus of the thematic, as with constructivists, or remains in the phenomenic. Perhaps ironically, this argument is underscored by the fact that a boiled -down version of constructivism has been put forward to highlight that ideas matter. Certainly, there is a need to (re)introduce some other causal factors to escape from the neo-neo consensus.

Andrew Moravcsik argues that all of these factors outlined here are clearly derived from liberalism, and thus distinct from realism and neoinstitutionalism and close to the transnationalism of the 1970s. However, as the same author points out, 'leading IR theorists', some of which have liberal leanings, 'freely concede the absence of coherent microfoundational assumptions' in this kind of hidden school, and even 'conclude therefrom that a liberal IR theory in the social sciences sense cannot exist' (Moravcsik, 1997: 514).

At the same time, the reformulation of liberalism as a paradigm should allow us to 'overcome a disjuncture between contemporary empirical research on world politics and the language employed by scholars to describe IR as a field', who continue to speak 'as if the dominant theoretical cleavage in the field were the dichotomy between realism and ('neoliberal') institutionalism' (Moravcsik, 1997: 514). Indeed, while it has been argued that the analytical axis must not nor cannot incorporate all the elements present in phenomenic reflections, the frequency with which scholars from different theoretical backgrounds turn to the domestic, transnational and cognitive factors when they seek to describe reality represents a kind of anomaly. It points to the need to consider the possibility of opening up analytical reflections. Consequently, some academics have put forward propositions, of varying degrees of complexity, to reconsider the neo-neo consensus on the analytical axis.

One of the most popular formulations is Robert Putnam's (1988) metaphor ${ }^{18}$ of two-level games, in which statesmen must move between the international and the domestic fields with the objective of winning in both at the same time, or, at the very least, ensuring the compatibility of the results from both playing fields (Kydd and Snidal, 1993: 130-1). Jeffrey Knopf has pointed out several limitations which the metaphor of two-level games must overcome. Firstly, it should 'give adequate attention to the differences among three logically separable forms of domesticinternational interaction', which he labels 'transgovernmental, transnational, and cross-level' (that occurs between governmental and private participants from different countries). Secondly, it should 'give due regard to institutional links among groups of states such as exist in a military alliance'. And finally, according to Knopf, it should pay due attention 'to the possibility that negotiating propositions or even the initiation of negotiations can be generated by the actions of domestic groups' (Knopf, 1993: 600). In any case, both Putnam's proposals and Knopf's ones move us in the direction of re-opening the analytical debate in International Relations.

${ }_{18}$ Putnam himself understands that the two-level games model is only a 'metaphor' (Putnam, 1988: 433). This has led to criticism like that of Helen Milner, who understands that 'although promising as a framework for analysis, this approach does not constitute a theory with testable hypotheses' (Milner, 1997: 4). 
The suggestion made by Helen Milner can also be understood in this same vein, whereby she favours the interpretation of the domestic arena not as a hierarchic system, but rather as a 'polyarchy', shaped by the influence of interests, institutions and information. According to Milner, 'cooperative agreements [among states] create winners and losers domestically', so that 'the internal struggle between these groups shapes [their] possibility and nature'. In effect, to conceive domestic politics as a polyarchy has profound implications for the study of international politics, given that it involves assuming that 'cooperation among nations is affected less by fears of other countries' relative gains or cheating than it is by the domestic distributional consequences of cooperative endeavors'. In other words, it involves assuming that 'rather than the struggle for state survival taking priority, the struggle for internal power and compromise dominates foreign policy making' (Milner, 1997: 9, 10, 14).

Andrew Moravcsik has also developed a proposition which should allow for the reopening of analytical debates. In this respect, the author explicitly seeks to present 'a set of core assumptions on which a general restatement of positive liberal IR theory can be grounded', which involves placing 'statesociety relations at the center of world politics' (Moravcsik, 1997: 515; 2003: 5). More specifically, Moravcsik's proposition is articulated around three variants of liberal theory: ideational liberalism, which understands that 'the configuration of domestic social identities and values' are a 'basic determinant of state preferences and thus of interstate conflict and cooperation'; commercial liberalism, that emphasizes the role of 'economic assets and cross-border transactions', and that takes into account the 'market incentives facing domestic and transnational economic actors'; and finally, republican liberalism, that underlines 'the ways in which domestic institutions and practices aggregate [societal identities and economic interests], transforming them into state policy'19 (Moravcsik, 2003: 10-15).

Along similar lines, and with the explicit aim of 'bringing transnational relations back in', Thomas Risse-Kappen endeavours to analyse 'under what domestic and international circumstances do transnational coalitions and actors who attempt to change policy outcomes in a specific issuearea succeed or fail to achieve their goals'. More precisely, he argues that the impact of transnational actors depends on 'domestic structures' (political institutions of the state, societal structures and policy networks linking the two), and the 'degrees of international institutionalization' (RisseKappen, 1995: 5-6).

Overall, several authors are making attempts that, albeit in different ways, tend towards the reopening of the analytical axis in order to allow the expression of certain phenomenic statements linked to the role of the domestic, the transnational and the cognitive. In short, there is a tendency towards the recovery for theoretical debate of certain formulations from old transnationalism (which, it might be added, partially retraces the steps of the neo-neo convergence).

By way of conclusion, the paper has argued that the convergence between the analytical frameworks of (neo)realism and of (neo)institutionalism has removed the oldest theoretical confrontation in International Relations from its privileged place in the literature. The challenge of neoinstitutionalism may have demonstrated that co-operation is viable even in a realist world, but

${ }^{19}$ Along the same lines, see Kahler (2000: 667); Cowhey (1993: 299); Milner (1997: 18 and 19). 
to some extent this is as far as it goes, leading to the exhaustion of the debate between both sides. However, as soon as one moves away from the usual way of classifying the literature, some of the debates traditionally associated with realism and institutionalism re-emerge in other parts of the discipline, although in different forms and with different names. Our paper has sought to show that the classification inspired in Holton's three axes allows such a transformation and its causes to be more clearly identified.

We have also defended the idea that IR as a whole should recover some of the issues for analytical discussion that during the 1970s had been at the centre of the discipline and that since then had been confined to the field of phenomenic assertions. In effect, a discipline with a strong mainstream, which, in the language of Kuhn, is a discipline that seeks to develop as a normal science as opposed to being constantly subjected to scientific revolutions, needs vigorous analytical debates that are supported by work on the phenomenic, while the latter must have theoretical projection.

\section{References}

Abbott, Kenneth W. and Duncan Snidal. 2000. Hard and soft law in international governance. International Organization, 54 (3): 421-456.

Axelrod, Robert. 1984. The evolution of cooperation. New York: Basic Books, Inc., Publishers.

Axelrod, Robert and Robert 0. Keohane. 1986. Achieving cooperation under anarchy: strategies and institutions. In Oye Kennetg (ed). Cooperation under anarchy, pp. 226-54. Princeton: Princeton University Press.

Banks, Michael. 1985. The Inter-Paradigm Debate. In Margo Light and AJR Groom (eds). International relations. A handbook of current theory, pp. 7-26. London: Pinter Publishers.

Barbé, Esther. 1987. El papel del Realismo en las Relaciones Internacionales. (La teoría de la política internacional de Hans J Morgenthau). Revista de Estudios Políticos, 57: 149-176.

Bernstein, Steven. 2000. Ideas, social structure and the compromise of liberal environmentalism. European Journal of International Relations, 6 (4): 464-512.

Corrales, Javier and Richard E. Feinberg. 1999. Regimes of cooperation in the Western Hemisphere : power, interests, and intellectual traditions. International Studies Quarterly, 43: 1-36.

Cowhey, Meter F. 1993. Domestic institutions and the credibility of international commitments: Japan and the United States. International Organization, 47 (2): 299-326.

Feaver, Peter D; Gunther Hellman; Randall L. Taliaferro; William C. Wohlforth; Jeffrey W. Legro and Andrew Moravcsik. 2000. Brother, Can You Spare a Paradigm? (Or Was Anybody Ever a Realist?). International Security, 25 (1): 165-193.

Gilpin, Robert R. 1986. The richness of the tradition of political realism. In Robert O. Keohane (eds). Neorealism and its critics, pp. 301-21. New York: Columbia University Press.

Glaser, Charles L. 1994/95. Realist as optimists. Coordination and self-help. International Security, 19 (3): $50-90$

Grasa, Rafael. 1997. La reestructuración de la teoría de las Relaciones Internacionales en la posguerra fría: el realismo y el desafío del liberalismo neoinstitucional. Cursos de Derecho Internacional y de Relaciones Internacionales de Vitoria-Gasteiz 1996, Madrid: Tecnos/UPV, 103-147. 
Grieco, Joseph. 1990. Cooperation among nations. Europe, America, and non-tariff barriers to trade. Ithaca/London: Cornell University Press.

Grieco, Joseph. 1993. The relative-gains problem for international cooperation. Comment. The American Political Science Review, 87 (3): 729-735.

Grieco, Joseph. 1995. Anarchy and the limits of cooperation: a realist critique of the newest liberal institutionalism. In Charles W. Kegley Jr. (eds). Controversies in International Relations Theory. Realism and the Neoliberal Challenge, pp. 151-71. New York: St. Martin's Press.

Gruber, Lloyd. 2000. Ruling the World: Power Politics and the Rise of Supranational Institutions. Princeton, N.J.: Princeton University Press.

Guzzini, Stefano. 1998. Realism in International Relations and International Political Economy. The continuing story of a death foretold. London: Routledge.

Haas, Peter M. 1990. Saving the Mediterranean. The politics on international cooperation. New York: Columbia University Press.

Haas, Peter M. 1993. Epistemic communities and the dynamics of international environmental cooperation. In Volker Rittberger (eds). Regime theory and international relations, pp. 168-201. Oxford: Clarendon Press.

Hasenclever, Andreas; Peter Mayer and Volder Rittberger. 1997. Theories of International Regimes. Cambridge: Cambridge University Press.

Hoffmann, Stanley. 1963. Contemporary Theory in International Relations. Prentice-Hall International, Inc.: Englewood Cliffs.

Holton, Gerald. 1973. Thematic Origins of Scientific Thought: Kepler to Einstein. Cambridge: Harvard University Press. Revised edition 1988.

Holton, Gerald. 1975. On the Role of Themata in Scientific Thought. Science, 188, April 25: 328-334.

Holton, Gerald. 1998. The Scientific Imagination. Cambridge: Harvard University Press.

Holton, Gerald. 2003. Perspectives of the Thematic Analysis of Scientific Thought. Paper at Rabat Symposium. http://www. Autodidactproject.org/other/ themata1.html

Hurrell, Andrew. 1993. International society and the study of regimes. A reflective approach. In Volker Rittberger (eds). Regime theory and international relations, pp. 49-72. Oxford: Clarendon Press.

Hurrell, Andrew and Benedict Kingsbury. 1992. The international politics of the environment: an introduction. In Andrew Hurrell and Benedict Kingsbury (eds). The international politics of the environment. Actors, interests and institutions, pp. 1-47. Oxford: Clarendon Press.

Jervis, Robert. 1999. Realism, neoliberalism and cooperation. International Security, 24 (1): 42-63.

Kahler, Miles. 2000. Conclusion: the causes and consequences of legalization. International Organization, 54 (3): 661-683.

Keck, Otto. 1993. The new institutionalism and the relative-gains-debate. In Frank R. Pfetsch (eds). International Relations and Pan-Europe. Theoretical approaches and empirical findings, pp. 3562. Hamburg: Lit Verlag.

Kegley, Charles W. Jr. 1995. The neoliberal challenge to realist theories of international politics: an introduction. In Charles W. Jr. Kegley (eds). Controversies in International Relations Theory. Realism and the Neoliberal Challenge, pp. 1-24. New York: St. Martin's Press.

Keohane, Robert 0. 1984. After the hegemony. Cooperation and discord in the world political economy. Princeton: Princeton University Press.

Keohane, Robert 0. 1986. Theory of world politics: structural realism and beyond. In Robert O. Keohane (eds). Neorealism and its critics, pp. 158-203. New York: Columbia University Press. 
Keohane, Robert 0. 1989. International Institutions and State Power. Boulder: Westview Press.

Keohane, Robert O. and Lisa L. Martin, Lisa. 1995. The promise of institutional theory. International Security, 20 (1): 39-51.

Keohane, Robert O. and Joseph S. Nye. 1971. Transnational relations and world politics. Cambridge/London: Harvard University Press.

Keohane, Robert O. and Joseph S. Nye. 1977. Power and interdependence. World politics in transition. Boston/Toronto: Little, Brown and Company.

Knopf, Jeffrey W. 1993. Beyond two-level games: domestic-international interaction in the intermediaterange nuclear forces negotiations. International Organization, 47 (4): 599-628.

Krasner, Stephen D. 1983. Regimes and the limits of realism: regimes as autonomous variables.

In Stephen D. Krasner (eds). International Regimes, pp. 355-368. Ithaca, N.Y: Cornell University Press.

Kydd, Andrew and Duncan Snidal. 1993. Progress in game-theoretical analysis of international regimes. In Volker Rittberger (eds). Regime theory and international relations, pp. 112-135. Oxford: Clarendon Press.

Lapid, Yosef. 1989. The third debate: on the prospects of international theory in post-positivist era. International Studies Quarterly, 33 (3): 235-254.

Legro, Jeffrey W. and Andrew Moravcsik. 1999. Is anybody still a Realist?. International Security, 24 (2): 5-55.

Levy, Marc A.; Oran R. Young and Michael Zürn. 1995. The Study of International Regimes. European Journal of International Relations, 1 (3): 267-330.

Liftin, Karen T. 1995. Framing science: precautionary discourse and the ozone treaties. Millenium: Journal of International Studies, 24 (2): 251-277.

List, Martin and Volker Rittberger. 1992. Regime theory and international environmental management. In Andrew Hurrell and Benedict Kingsbury (eds). The international politics of the environment. Actors, interests and institutions, pp. 85-109. Oxford: Clarendon Press.

Markova, Ivana. 2004. Generating socially shared knowledge from themata. htpp://webhost.uab.ac.be/tisp/

Mayer, Frederick W. 1992. Managing domestic differences in international negotiations: the strategic use of internal side-payements. International Organization, 46 (4): 793-818.

Mearsheimer, John J. 1994/95. The false promise of international institutions. International Security, 19 (2): $5-49$.

Merton Robert K. 1975. Thematic Analysis in Science: notes on Holton's Concept. Science, 188, April 25: 335-388.

Milner, Helen. 1992. International theories of cooperation among nations. Strengths and weaknesses. World Politics, 44: 466-496.

Milner, Helen V. 1997. Interests, institutions, and information. Domestic politics and international relations. Princeton: Princeton University Press.

Milner, Helen. 1998. Rationalizing politics: the emerging synthesis of international, American, and comparative politics. International Organization, 52 (4): 759-786.

Moravcsik, Andrew. 1997. Taking preferences seriously: a liberal theory of international politics. International Organization, 52 (1): 513-553.

Moravcsik, Andrew. 2003. Liberal international relations theory. A scientific assessment. Colin Elman and Miriam Fendius Elman (eds). Progress in international relations theory, Cambridge, MA: MIT Press. Found at the website, http://www.Princeton.edu/ amoravcs (accessed date: March 2004). 
Morgenthau, Hans J. 1948. Politics Among Nations. The Struggle for Power and Peace (Fifth Edition, 1973). New York: Alfred A. Knopf, Inc.

Powell, Robert. 1994. Anarchy in International relations theory: the neorealist-neoliberal debate. International Organization, 48 (2): 313-344.

Putnam, Robert. 1988. Diplomacy and domestic politics: the logic of two level games. International Organization, 42 (3). 427-460.

Risse-Kappen, Thomas. 1995. Bringing Transnational Relations Back In: Introduction. In Thomas RisseKappen (eds). Bringing Transnational Relations Back In. Non-State Actors, Domestic Structures and International Institutions, pp. 3-33. Cambridge: Cambridge University Press.

Rittberger, Volker and Michael Zürn. 1990. Towards regulated anarchy in East-West relations: causes and consequences of East-West regimes. Volker Rittberger (eds). International Regimes in East-West Politics, pp. 9-63. London/New York: Pinter Publishers.

Rosecrance, Richard. 2001. Has Realism Become Cost-Benefit Analysis?. A Review Essay. International Security, 26 (2): 132-154.

Snidal, Duncan. 1991. Relative gains and the pattern of international cooperation. The American Political Science Review, 85 (3): 701-726.

Snidal, Duncan. 1993. The relative-gains problem for international cooperation. Response. The American Political Science Review, 87 (3): 738-743.

Taylor, Michael. 1987. The possibility of cooperation. Cambridge/New York: Cambridge University Press. Waltz, Kenneth N. 1979. Theory of International Politics. Reading: Adison-Wesley.

Waltz, Kenneth N. 1986. Reflections on Theory of International Politics. A response to my critics. In Robert 0. Keohane (eds). Neorealism and its critics, pp. 322-345. New York: Columbia University Press.

Waever, Ole. 1996. The rise and fall of the inter-paradigm debate. In Steve Smith; Ken Booth and Marysia Zalewski (eds). International theory: positivism and beyond, pp. 149-183. Cambridge and New York: Cambridge University Press.

Young, Oran R. 1989. International Cooperation. Building regimes for natural resources and the environment. New York: Cornell University Press. 